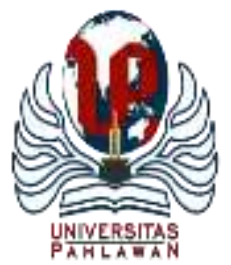

Edukatif : Jurnal Ilmu Pendidikan Volume 4 Nomor 1 Tahun 2022 Halm 1378 - 1386

EDUKATIF: JURNAL ILMU PENDIDIKAN

Research \& Learning in Education

https://edukatif.org/index.php/edukatif/index



\title{
Media Pembelajaran Bahasa Arab Berbasis Teknologi Informasi Komunikasi pada Pembelajaran Daring di Sekolah Dasar
}

\author{
Almi Novita ${ }^{1 凶}$, Munawir $^{2}$ \\ Universitas Islam Negeri Sunan Ampel Surabaya, Indonesia ${ }^{1,2}$ \\ E-mail : almialminovita@gmail.com ${ }^{1}, \underline{\text { munawirpgmi@gmail.com }}{ }^{2}$
}

\begin{abstract}
Abstrak
Sejak masuknya pandemi Covid-19 ke Indonesia, berbagai satuan pendidikan telah banyak mengalami perubahan khususnya pada penggunaan media pembelajaran dalam kegiatan belajar mengajar. Seluruh kegiatan belajar mengajar dialihkan dengan menggunakan media pembelajaran berbasis TIK (Teknologi Informasi dan Komunikasi). Penulisan artikel ini bertujuan untuk mengkaji media-media yang digunakan pada saat kegiatan pembelajaran Bahasa Arab di SD Al-Fatah Surabaya selama pelaksanaa pembelajaran secara daring. Metode yang digunakan dalam penelitian ini adalah kualitatif deskriptif. Hasil dari Penelitian ini menunjukkan bahwa media pembelajaran yang digunakan untuk menyampaikan materi pembelajaran Bahasa Arab di SD Al-Fatah berbasis TIK terdiri dari Slide Power Point, Canva, Google Slide dan media lainnya yang digunakan sebagai media presentasi penunjang pemahaman siswa, Zoom Meeting dan Google Meet digunakan sebagai media pertemuaan (pengganti pembelajaran luring di kelas), dan untuk media pembelajaran secara mandiri menggunakan Google Teams dan Google Classroom. Pada pelaksanaan kegiatan pembelajaran Bahasa Arab melalui aplikasi Zoom Meeting berbasis TIK berlangsung, siswa cukup interaktif dan simulatif dalam melafalkan setiap kosa kata atau mufrodat yang disampaikan oleh guru.
\end{abstract}

Kata Kunci: Media Pembelajaran, TIK, Bahasa Arab.

\begin{abstract}
Since the entry of the Covid-19 pandemic into Indonesia, various educational units have undergone many changes, especially in the use of learning media in teaching and learning activities. All teaching and learning activities are transferred to using ICT-based learning media. Writing this article aims to examine the media used during Arabic learning activities at Al-Fatah Elementary School Surabaya during the implementation of online learning. The method used in this research is descriptive qualitative. The results of this study indicate that the learning media used to deliver Arabic learning materials at Al-Fatah Elementary School based on ICT consist of Power Point Slides, Canva, Google Slides and other media used as presentation media to support student understanding, Zoom Meeting and Google Meet. used as a meeting medium (a substitute for offline learning in class), and for independent learning media using Google Teams and Google Classroom. In the implementation of Arabic learning activities through the ICT-based Zoom Meeting application, students were quite interactive and simulative in reciting every vocabulary conveyed by the teacher.
\end{abstract}

Keywords: Learning Media, ICT, Arabic.

Copyright (c) 2022 Almi Novita, Munawir

$\checkmark$ Corresponding author

Email : almialminovita@gmail.com

DOI : https://doi.org/10.31004/edukatif.v4i1.1947

ISSN 2656-8063 (Media Cetak)

ISSN 2656-8071 (Media Online) 
1379 Media Pembelajaran Bahasa Arab Berbasis Teknologi Informasi Komunikasi pada Pembelajaran Daring di Sekolah Dasar-Almi Novita, Munawir

DOI: https://doi.org/10.31004/edukatif.v4i1.1947

\section{PENDAHULUAN}

Berbagai satuan pendidikan telah banyak mengalami perubahan khususnya dalam penggunaan media pembelajaran pada saat kegiatan belajar mengajar sejak masuknya pandemi Covid-19 ke Indonesia. Pembelajaran dimasa pandemi mengharuskan seluruh lembaga pendidikan baik formal maupun non formal untuk dapat menjalankan dan menyesuaikan seluruh kegiatan belajar mengajar sebagaimana pembelajaran dalam kelas dengan memanfaatkan media pembelajaran berbasis TIK (Teknologi Informasi dan Komunikasi). Akan tetapi pada penerapannya, pembelajaran secara daring tidak semudah yang dibayangkan, karena pada pelaksanaannya terdapat banyak keterbatasan media pendukung (fasilitas) pembelajaran daring, selain itu kemampuan guru yang terbatas dalam mengoperasikan media berbasis TIK khususnya guru senior, serta membutuhkan biaya yang tidak sedikit, sehingga pada pelaksanaannya dibutuhkan kerjasama antara guru dan orang tua demi keberhasilan kegiatan pembelajaran.(Dewi, 2020).

Kehadiran TIK (Teknologi Informasi dan Komunikasi) dalam dunia pendidikan memberikan perubahan yang cukup mendasar, khususnya dimasa pandemi seperti saat ini, dimana seluruh kegiatan diharuskan untuk tetap berjalan sebagaimana mestinya dengan memanfaatkan TIK (Teknologi Informasi dan Komunikasi). (Hanifah Salsabila et al., 2020) Penggunaan TIK dapat membantu guru pada saat menyampaikan materi pembelajaran kepada peserta didiknya. Namun, pada pembelajaran daring guru dituntut untuk dapat lebih kreatif agar dapat tercipta suasana belajar yang menyenangkan dengan memanfaatkan berbagai fasilitas pendukung pembelajaran berupa media-media berbasis TIK secara maksimal dan efektif, karena dengan menggunakan media pembelajaran berbasis TIK seorang guru dapat menyampaikan materi pembelajaran melalui visualisasi dan animasi, sehingga dapat meningkatkan ketertarikan dan pemahaman siswa pada saat kegiatan belajar mengajar khususnya pada saat pembelajaran Bahasa Arab yang sebagian besar siswa menganggap sulit untuk dipahami. (Putri \& Nurafni, 2021).

Pembelajaran Bahasa Arab termasuk dalam rumpun Pendidikan Agama Islam, keduanya memiliki pengaruh dan peranan yang sangat penting dalam memahami setiap ajaran yang ada dalam agama Islam. Sebagaimana kita ketahui bahwa dalam memahami ajaran Islam tidak dapat terlepas dari pengetahuan mengenai Bahasa Arab, Agama Islam diibaratkan sebagai suatu rumah, sedangkan Bahasa Arab diibaratkan sebagai pintunya, karena sumber-sumber ajaran Islam yang hingga saat ini kita jadikan sebagai pedoman yakni Al-Qur'an merupakan sebuah kitab pedoman berbahasa Arab yang harus kita fahami dan dalami. (Rahman, 2019) Dalam mempelajari dan memahami Bahasa Arab cukup sulit, terkhusus bagi siswa yang belum pandai dalam membaca Al-Qur'an, sehingga berpengaruh pada motivasi belajar siswa yang berakibat pada kurangnya respon yang diberikan oleh siswa pada saat kegiatan pembelajaran berlangsung, khususnya pada pembelajaran daring dimana siswa tidak berhadapan secara langsung dengan gurunya.

Beberapa peneliti terdahulu telah memaparkan mengenai media-media pembelajaran berbasis TIK berbentuk aplikasi yang dapat digunakan sebagai penunjang pemahaman siswa di era industry 4.0 khususnya saat ini ketika seluruh kegiatan pembelajaran dilaksanakan secara daring. Namun, yang membedakan antara peneliti terdahulu dengan penelitian ini adalah terletak pada bagaimana guru mengimplementasikan mediamedia pembelajaran berbasis TIK kepada para siswanya ketika pembelajaran Bahasa Arab secara daring berlangsung. Karena pada pembelajaran Bahasa Asing terutama pada pembelajaran Bahasa Arab, proses pembelajaran tidak hanya terfokus pada pelafalan mufrodat (kosa kata) saja, akan tetapi juga pada pengembangan serta penerapan bahasa siswa dalam kehidupan sehari-hari.

Tujuan dari penelitian ini adalah untuk dapat mengetahui bagaimana strategi yang dilakukan guru Bahasa Arab dalam mengimplementasikan media pembelajaran berbasis TIK selama pembelajaran Bahasa Arab secara daring. Dan bagaimana bagaimana strategi yang dilakukan guru Bahasa Arab untuk dapat menciptakan suasana pembelajaran daring yang interaktif dan menyenangkan sebagaimana pembelajaran dalam kelas, agar pembelajaran Bahasa Arab tidak lagi mendapat stigma negatif yang berimbas pada 
1380 Media Pembelajaran Bahasa Arab Berbasis Teknologi Informasi Komunikasi pada Pembelajaran Daring di Sekolah Dasar-Almi Novita, Munawir

DOI: https://doi.org/10.31004/edukatif.v4i1.1947

minimnya motivasi masyarakat untuk mempelajari Bahasa Arab. Maka, dalam artikel ini penulis akan memaparkan mengenai media-media berbasis TIK yang digunakan pada saat proses pembelajaran Bahasa Arab pada Pembelajaran Daring di SD Al-Fatah Surabaya.

\section{METODE PENELITIAN}

Metode yang digunakan dalam penelitian ini adalah metode kualitatif deskriptif. Pada penelitian ini, data yang dikumpulkan berupa kata-kata yang tertulis maupun secara lisan bermakna yang dapat memacu pemahaman peneliti. Dengan demikian peneliti dapat mendeskripsikan dan menggambarkan situasi yang sesungguhnya pada saat penyajian data sebagaimana bentuk aslinya pada saat pengumpulan data. (Nugrahani, 2014: 96) Penelitian dilaksanakan di SD Al-Fatah Surabaya yang terletak di jalan Dukuh Karangan Gg Golongan, Babatan, Kec. Wiyung, Kota Surabaya selama dua bulan. Kehadiran peneliti dalam penulisan artikel ini adalah sebagai pengumpul data utama yang diawali dengan melakukan wawancara bersama guruguru khususnya guru Bahasa Arab dan kepala sekolah SD Al-Fatah Surabaya. Selain melakukan wawancara, sebagai langkah observasi dilakukan oleh peneliti, diantaranya adalah dengan mengikuti proses kegiatan pembelajaran daring untuk memperoleh data tambahan dan mengecek keabsahan data yang telah di dapatkan.

Langkah-langkah yang digunakan untuk menguji keabsahan data yakni dengan melakukan uji credibility dengan memperpanjangan pengamatan, meningkatkan kecermatan dalam penelitian dan Triangulasi. (Sugiyono, 2016) Perpanjangan pengamatan dilakukan dengan mengikuti pembelajaran secara daring melalui aplikasi Zoom Meeting untuk menguji kredibilitas data penelitian yang difokuskan pada pengujian data yang diperoleh dengan mengecek langsung ke lapangan, sehingga data yang dihasilkan dapat dipertanggungjawabkan kebenarannya (kredibel). Kemudian untuk meningkatkan kecermatan dalam penelitian, peneliti membaca berbagai referensi yang berasal dari buku, hasil penelitian terdahulu dan dokumen-dokumen terkait guna membandingkan hasil penelitian yang telah diperoleh. Dan triangulasi dalam pengujian kredibilitas dilakukan dengan cara melakukan diskusi lebih lanjut bersama sumber data yang bersangkutan untuk memastikan kebenaran data yang telah diperoleh.

\section{HASIL DAN PEMBAHASAN PENELITIAN}

Pembelajaran daring merupakan konsep pembelajaran jarak jauh yang aktivitas pembelajarannya dapat dilaksanakan tanpa batasan ruang dan waktu. Pembelajaran daring mulai gencar diberlakukan di seluruh lembaga pendidikan baik di dalam maupun luar negeri sejak virus Covid-19 ditetapkan sebagai pandemi. Sistem pendidikan yang semula tatap muka, kini berganti menjadi tatap maya atau pembelajaran dalam jaringan (daring). Meskipun dalam penerapannya siswa dan guru dihadapkan pada berbagai problem, namun pembelajaran daring dapat menjadi solusi agar pembelajaran dapat tetap berjalan dan melalui pembelajaran daring siswa dituntut untuk dapat meningkatkan kemandiriannya dalam menghadapi kehidupan dikemudian hari. (Suriadi et al., 2021).

Pada dasarnya, pembelajaran daring merupakan pembelajaran yang dilakukan secara arinkronus dan sinkronus. Pembelajaran arinkronus merupakan kegiatan pembelajaran secara tidak langsung namun dalam waktu yang bersamaan. Pembelajaran ini dapat berupa pemberian tugas, diskusi, membaca materi pembelajaran, dan lain-lain. Namun, pembelajaran jenis ini cenderung fleksibel, sehingga bisa juga dilakukan tidak dalam waktu yang bersamaan. Sedangkan pembelajaran sinkronus merupakan pembelajaran tatap muka dalam waktu yang bersamaan baik secara luring maupun daring. Pembelajaran sinkronus secara luring dapat berupa pembelajaran tatap muka dalam kelas, penelitian di laboratorium, karya wisata, diskusi kelompok dan lain-lain. Sedangkan Pembelajaran sinkronus secara daring dapat berupa live streaming, konferensi audio dan video, pertemuan melalui zoom meeting, dan lain-lain. (Handriyantini, 2020). 
Pemberlakuan pembelajaran secara daring, secara tidak langsung mampu menumbuhkan rasa kemandirian belajar siswa (self regulated learning), karena pembelajaran daring pada prosesnya berpusat pada siswa, sehingga dapat memunculkan rasa tanggung jawab siswa untuk dapat menyelesaikan seluruh tugas dengan tepat waktu. Selain dari pada hal itu, kegiatan pembelajaran daring juga dapat meningkatkan minat peserta didik karena pada prosesnya, pembelajaran berbasis daring dengan memanfaatkan TIK (Teknologi Informasi dan Komunikasi) berupa audio visual pada saat menyampaikan materi pembelajaran. (Sadikin \& Hamidah, 2020).

Pandemi sudah berjalan hampir 2 tahun lamanya, dan hingga saat ini pembelajaran secara daring masih tetap diberlakukan diseluruh lembaga pendidikan mulai dari pendidikan dasar hingga perguruan tinggi. Bersamaan dengan hal ini, berbagai inovasi dan pengembangan-pengembangan bahan ajar telah diterapkan di seluruh lembaga pendidikan guna menunjang proses kegiatan pembelajaran secara daring. Sayangnya, pemanfaatan TIK (Teknologi Informasi dan Komunikasi) pada pembelajaran daring jika di terapkan kepada siswa yang tinggal di beberapa daerah khususnya daerah-daerah yang ada di pelosok negeri dan tidak ditemukan akses internet yang baik, pelaksanaannya kurang efektif dan efisien. (Sadikin \& Hamidah, 2020). Sehingga pembelajaran daring hanya dapat diakses dan mudah untuk diterapkan bagi siswa yang tinggal didaerah yang memiliki akses internet yang cukup baik, selain dari pada hal itu biaya yang dibutuhkan untuk memfasilitasi pembelajaran daring juga relatif mahal.

\section{Media Pembelajaran Berbasis TIK (Teknologi Informasi dan Komunikasi)}

Dalam berkomunikasi kita membutuhkan suatu sarana atau media. Secara umum media dimaknai dengan hal-hal apa saja yang dapat digunakan untuk dapat menyalurkan informasi dari sumber informasi kepada penerima informasi. Media pembelajaran merupakan suatu perangkat lunak (software) berupa pesan atau informasi mengenai pendidikan yang disajikan menggunakan perangkat bantu (hardware) agar informasi atau pesan tersebut dapat tersampaikan kepada sasarannya (peserta didik). (Widianto, Edi., 2021) Media pembelajaran diibaratkan sebagai jembatan atau saluran berupa pesan-pesan pembelajaran yang disampaikan oleh sumber pesan (guru) kepada penerima pesan (siswa). Kehadiran media pembelajaran sebagai penyampai pesan adalah agar pesan-pesan tersebut dapat diserap dengan cepat dan tepat sesuai dengan tujuannya. (Wahyuningtyas \& Sulasmono, 2020) Media pembelajaran juga dapat diibaratkan sebagai sebuah wadah dari sumber atau penyalur informasi (Pengajar) sebagai usaha untuk dapat menyampaikan informasi pendidikan kepada sasaran atau penerima informasi (peserta didiknya). Sehingga dapat mencapai tujuan yang hendak dicapai, yakni terjadinya proses belajar mengajar. (Muhson, 2010).

Teknologi informasi dan komunikasi terus berkembang dengan sangat pesat. Hal demikian ditunjukkan dengan penggunaan teknologi informasi dan komunikasi yang sangat masif di gunakan di berbagai bidang, salah satunya pada bidang pendidikan. Sebelum pandemi Covid-19 penggunaan media pembelajaran berbasis TIK (Teknologi Informasi dan Komunikasi) telah banyak digunakan di berbagai lembaga pendidikan. Namun, sejak diberlakukan pembelajaran secara daring, penggunaannya kini semakin masif. Perkembangan teknologi informasi dan komunikasi memungkinkan seluruh elemen pendidikan untuk melakukan pembelajaran jarak jauh kapanpun dan dimanapun tanpa terikat jarak.

Seluruh lembaga pendidikan menggunakan TIK sebagai media pembelajaran dengan memanfaatkan internet sebagai media interaktif pengganti pembelajaran di kelas. Pemanfaatan TIK (Teknologi Informasi dan Komunikasi) sebagai media pembelajaran dimasa pandemi dianggap sebagai solusi yang paling tepat untuk dapat merangsang pikiran, perasaan, minat, serta perhatian siswa sebagaimana pembelajaran di kelas. (Dewi \& Hilman, 2019: 48). 
1382 Media Pembelajaran Bahasa Arab Berbasis Teknologi Informasi Komunikasi pada Pembelajaran Daring di Sekolah Dasar-Almi Novita, Munawir

DOI: https://doi.org/10.31004/edukatif.v4i1.1947

\section{Pembelajaran Bahasa Arab di SD Al-Fatah Surabaya}

Saat ini, masyarakat semakin sadar akan kebutuhannya dalam mempelajari dan memahami Bahasa Arab, selain agar dapat membaca dan memahami setiap makna yang tersirat dalam Al-Qur'an sebagai pedoman kita dalam beragama, mempelajari Bahasa Arab juga dapat mepermudah kita dalam memahami setiap ilmu pengetahuan dan ajaran Islam agar dapat diterapkan dalam kehidupan sehari-hari dengan baik. Kesadaran inilah yang kemudian banyak dari lembaga pendidikan yang menjadikan Bahasa Arab sebagai salah satu mata pelajaran yang di ajarkan di dalam kelas. (Cholis et al., 2020: 366).

SD Al-Fatah Surabaya merupakan salah satu lembaga pendidikan berbasis Islam yang menyadari akan pentingnya pembelajaran Bahasa Arab untuk diajarkan kepada peserta didiknya. Namun, pembelajaran Bahasa Arab bukan merupakan mata pelajaran wajib, melainkan mata pelajaran ekstra yang disediakan oleh yayasan Al-Fatah sebagai bentuk persiapan bagi peserta didiknya yang hendak melanjutkan pendidikan formalnya ke sebuah lembaga pendidikan Islam (pesantren). Meskipun demikian, bukan berarti pembelajaran Bahasa Arab menjadi tidak menjadi penting bagi mereka yang hendak melanjutkan pendidikannya ke sekolah menengah yang tidak berbasis Islam. Pembelajaran Bahasa Arab penting untuk dijadikan sebagai bekal dalam memahami dasar-dasar ajaran Islam, karena Bahasa Arab termasuk dalam rumpun Pendidikan Agama Islam.

Di SD Al-Fatah Surabaya, pembelajaran Bahasa Arab hanya diajarkan pada siswa kelas 2 sampai dengan kelas 5. Pada setiap tingkatan kelasnya, siswa tidak dituntut untuk dapat memahami seluruh materi yang ada dalam buku pembelajaran Bahasa Arab, terlebih pada materi percakapan yang telah disesuaikan dengan dhomir-nya. Meskipun pada dasarnya bagi siswa kelas 4 dan 5 sudah diajarkan untuk dapat memperhatikan dan memahami setiap unsur kebahasaan dan struktur dhomir terkait tema-tema yang telah dibahas, namun materi ini dianggap masih sangat sulit untuk dipraktikan khususnya pada saat pembelajaran secara daring.

Penyajian materi pembelajaran Bahasa Arab di SD Al-Fatah tidak selalu terpaku pada buku pelajaran. Pembelajaran disampaikan dengan fokus pada penyampaian kosa kata atau mufrodat sebagai pijakan awal dalam berbahasa Arab yang disertakan dengan gambar-gambar sebagai penunjang pemahaman siswa. Pembelajaran dengan cara tersebut dilakukan dengan memberikan latihan-latihan soal yang diberikan sebagai tugas mingguan siswa, sehingga siswa dapat mengaplikasikan kosa kata atau mufrodat yang telah diajarkan dalam bentuk komunikasi secara lisan dan tulisan sederhana.

\section{Implementasi Media Pembelajaran Bahasa Arab Berbasis TIK pada Pembelajaran Daring}

Sejak diberlakukannya Studi From Home (SFH) sebagai dampak dari pencegahan virus Covid-19, seluruh kegiatan belajar mengajar dilaksanakan dari rumah tak terkecuali bagi seluruh siswa \& tenaga pendidik yang ada di SD Al-Fatah Surabaya. Untuk dapat mensiasati agar kegiatan belajar mengajar dapat tetap berjalan sebagaimana pembelajaran di dalam kelas, memanfaatkan media pembelajaran berbasis TIK menjadi solusi yang paling efektif dan efisien untuk di terapkan selama proses pembelajaran daring. Namun, meski demikian, pada penerapannya guru dan siswa tetap menggunakan media pembelajaran manual (media cetak) seperti: Buku Teks, LKS, Modul, dan lain-lain sebagai penunjang pemahaman siswa selama pelaksanaan pembeajaran daring.

Pada proses kegiatan pembelajaran Bahasa Arab secara daring hal penting yang perlu di perhatikan oleh para tenaga pendidik adalah mengenai kompetensi guru dalam memanfaatkan TIK. Kompetensi yang dimaksud adalah dalam hal penguasaan dan pengembangan media pembelajaran Bahasa Arab menggunakan perangkat TIK (Teknologi Informasi dan Komunikasi). Dalam hal ini, guru Bahasa Arab di SD Al-Fatah Surabaya cukup menguasai standar kompetensi guru dalam penguasaan pembelajaran Bahasa Arab berbasis TIK, hal ini dibuktikan dengan penguasaan guru dalam memilih dan mengoperasikan media, aplikasi, dan perangkat TIK lainnya yang tepat bagi peserta didiknya sehingga dapat menunjang proses belajar mengajar. (Dewi \& Hilman, 2019: 51). 
Dalam pembelajaran Bahasa Arab penguasaan kosa kata atau mufrodat merupakan salah satu pijakan awal untuk dapat mempelajari, memahami dan menerapkan Bahasa Arab. (Cholis et al., 2020: 366) Dengan adanya media pembelajaran berbasis TIK, penguasaan kosa kata atau mufrodat dapat lebih mudah untuk dipahami dan diterapkan kepada peserta didik, karena melalui media berbasis TIK pembelajaran dapat lebih mudah untuk di akses dan siswa dapat mengulang-ulang pembelajaran secara mandiri. Maka, penggunaan media pembelajaran berbasis TIK dimasa pandemi pada pembelajaran daring berperan penting dalam menunjang pemahaman siswa, karena dengan adanya media pembelajaran dapat mempermudah guru dalam menyampaikan materi dan dapat lebih memudahkan siswa dalam memahami dan menerapkan kosa kata dalam kehidupan sehari-hari.

Penggunaan media pembelajaran berbasis TIK secara tidak langsung dapat meningkatkan ketertarikan dan perhatian siswa, karena sebagian besar siswa lebih menyukai pembelajaran berbentuk visual melalui media berbasis TIK. Selain lebih menarik, pembelajaran berbasis TIK lebih menyenangkan dan terkesan tidak monoton, sehingga dapat meningkatkan motivasi siswa dalam mempelajari dan memahami kosa kata atau mufrodat Bahasa Arab. Hal ini dibuktikan dengan kegiatan pembelajaran melalui aplikasi Zoom Meeting berbasis TIK yang rutin dilaksanakan setiap minggunya. Selama kegiatan pembelajaran berlangsung, siswa cukup interaktif dan simulatif dalam melafalkan setiap kosa kata atau mufrodat yang disampaikan oleh guru, dengan demikian dapat dipahami bahwa pemanfaatan media pembelajaran berbasis TIK dapat merangsang pikiran, perasaan serta minat peserta didik sehingga proses pembelajaran dapat berjalan dengan baik, efektif dan efisien.

Media-media pembelajaran berbasis TIK yang digunakan untuk menunjang pembelajaran daring di SD Al-Fatah Surabaya diantaranya adalah Teknologi Komputer berupa perangkat keras (hardware) dan perangkat lunak (software), Teknologi Media (kamera, player audio dan player video). Teknologi Jaringan (Internet dan wifi), serta Teknologi Telekomunikasi (smartphone) untuk berkomunikasi bersama peserta didik/wali siswa. (Suryani, 2015) Penggunaan media pembelajaran TIK pada pembelajaran bahasa Arab yang dipraktikkan di SD Al-Fatah Surabaya selama ini masih memaksimalkan media-media yang telah ada dan digunakan sejak diberlakukan pembelajaran secara daring.

Diantara media-media yang digunakan adalah Slide Power Point dan media lainnya yang digunakan sebagai media presentasi penunjang pemahaman siswa, Zoom Meeting dan Google Meet digunakan sebagai media pertemuaan (pengganti pembelajaran luring di kelas), sedangkan untuk media pembelajaran secara mandiri menggunakan Google Teams dan Google Classroom. Media-media pembelajaran tersebut merupakan media pembelajaran yang akrab dan banyak digunakan oleh guru dalam menyampaikan materi dan tugas, karena dapat mempermudah dan mempercepat interaksi dan akses informasi antara guru dan siswa tanpa terikat ruang dan waktu. Namun, yang harus diperhatikan dalam pengguna media berbasis TIK adalah sarana serta biaya yang dibutuhkan cukup besar. Selain itu, agar proses pelaksanaan pembelajaran daring dapat berjalan secara maksimal guru dan siswa membutuhkan perangkat dan jaringan internet yang stabil. (A. Sulaeman, 2019).

Kehadiran media pembelajaran TIK tidak hanya mampu membantu berjalannya proses belajar mengajar, akan tetapi juga berfungsi sebagai alat bantu pembelajaran. Karena dalam praktiknya, TIK tidak hanya membantu guru dalam penyampaikan pembelajaran melalui beragam perangkat saja, akan tetapi juga berkaitan dengan pengembangan ilmu, khususnya pada ilmu Komunikasi dan Teknologi yang sangat bermanfaat bagi masyarakat modern yang serba digital, Sehingga dapat memberikan kontribusi yang sangat signifikan dalam kehidupan sosial masyarakat. Dalam mengimplementasikan media-media pembelajaran berbasis TIK di SD Al-Fatah Surabaya pada pembelajaran Bahasa Arab terdapat kelebihan dan kelemahan, diantara kelebihannya adalah:

1. Penggunaan media-media pembelajaran berbasis TIK dapat lebih mudah digunakan dan di terapkan pada saat proses pembelajaran secara daring, karena pembelajaran di dominasi dalam bentuk media dengan 
1384 Media Pembelajaran Bahasa Arab Berbasis Teknologi Informasi Komunikasi pada Pembelajaran Daring di Sekolah Dasar-Almi Novita, Munawir

DOI: https://doi.org/10.31004/edukatif.v4i1.1947

menampilkan gambar/video secara audio visual, sehingga dapat memperbaiki daya ingat siswa, menarik perhatian siswa serta dapat meningkatkan motivasi belajarnya.

2. Mempermudah para pengajar dalam melaksanakan kegiatan pebelajaran khususnya pada saat menjelaskan instruksi-instruksi yang rumit.

3. Dengan bantuan media pembelajaran TIK pembelajaran juga dapat di rancang secara interaktif dan lebih menyenangkan, sehingga dapat memperbaiki tingkat kehadiran dan konsentrasi dari para peserta didik.(Darimi, 2017).

Sedangkan untuk kelemahan dari penggunaan media pembelajaran berbasis TIK adalah:

1. Keterbatasan siswa dan wali dalam mengoperasikan media pembelajaran, sehingga terjadi berbagai hambatan dalam proses pembelajaran.

2. Alat untuk menunjang kegiatan pembelajaran daring berbasis TIK terlalu mahal untuk dimiliki, terutama biaya untuk pengadaan dan pengembangan program yang di rancang khusus untuk pembelajaran

3. Untuk dapat merancang dan memproduksi suatu program pembelajaran berbasis TIK tidaklah mudah, membutuhkan waktu dan keahlian khusus. (Darimi, 2017).

4. Akses internet yang belum merata, sehingga keterbatasan koneksi dapay menghambat proses pembelajaran.

Diantara media-media yang digunakan dan diimplementasikan pada pembelajaran daring terdapat banyak kelebihan dan kelemahan, karena tidak seluruh sekolah dapat mengimplementasikan pembelajaran daring di lembaga pendidikannya. Namun, dimasa pandemi seperti saat ini, kehadiran media pembelajaran TIK menjadi angin segar bagi seluruh bidang khususnya pada bidang pendidikan untuk dapat tetap melaksanakan kegiatan belajar mengajar meskipun dalam keadaan darurat. Agar pada pelaksanaannya dapat berjalan secara optimal, penggunaan perangkat media pembelajaran TIK harus senantiasa digunakan secara integratif, sebab pada pelaksanaannya membutuhkan integrasi sistem dan materi pembelajaran secara bersamaan. (Nafrin \& Hudaidah, 2021).

Kendala yang paling banyak dihadapi guru dan siswa dalam penggunaan media pembelajaran berbasis TIK selama pembelajaran daring adalah penggunaan perangkat keras (internet) dan media telekomunikasi (smartphone). Penggunaan media telekomunikasi dan biaya internet yang cukup mahal menjadi kendala terbesar dalam pelaksanaan kegiatan belajar daring, karena keduanya saling berkaitan dalam menunjang proses pembelajaran daring. Selain dari pada hal itu, kurangnya interaksi antara guru dan siswa, bahkan antar siswa itu sendiri. Sehingga dapat memperlambat terbentuknya values pada saat proses belajar mengajar. (Yazdi, 2012) Dengan demikian sebagai solusi dari kendala yang dihadapi di SD Al-Fatah, siswa yang terkendala media pembelajaran TIK terlebih dahulu dilakukan komunikasi antara guru dan wali siswa, bagi siswa yang sulit untuk dihubungi, diperbolehkan untuk melaksanaksanakan pembelajaran secara khusus di sekolah dan Home Visit secara berkala oleh wali kelas dari masing-masing siswa. (Asmuni, 2020).

\section{KESIMPULAN}

Berdasarkan hasil penelitian ini, pada pelaksanaan pembelajaran daring guru Bahasa Arab di SD AlFatah Surabaya cukup menguasai standar kompetensi guru dalam penguasaan pembelajaran Bahasa Arab berbasis TIK yang dibuktikan dengan penguasaan guru dalam memilih dan mengoperasikan media, aplikasi, dan perangkat TIK yang dapat menunjang proses kegiatan belajar mengajar. Media-media yang digunakan diantaranya adalah Slide Power Point, Canva, Google Slide dan media lainnya yang digunakan sebagai media presentasi penunjang pemahaman siswa, Zoom Meeting dan Google Meet digunakan sebagai media pertemuaan (pengganti pembelajaran luring di kelas), dan untuk media pembelajaran secara mandiri menggunakan Google Teams dan Google Classroom. Pada pelaksanaannya, kegiatan pembelajaran Bahasa Arab melalui aplikasi Zoom Meeting berbasis TIK lebih menarik perhatian siswa, ketika kegiatan 
1385 Media Pembelajaran Bahasa Arab Berbasis Teknologi Informasi Komunikasi pada Pembelajaran Daring di Sekolah Dasar - Almi Novita, Munawir

DOI: https://doi.org/10.31004/edukatif.v4i1.1947

pembelajaran berlangsung siswa cukup interaktif dan simulatif dalam melafalkan setiap kosa kata atau mufrodat yang disampaikan oleh guru. Namun, beberapa siswa terkendala dalam penggunaan media pembelajaran, sehingga siswa tersebut tidak dapat bergabung mengikuti pembelajaran berbasis TIK sebagaimana proses pembeajaran yang diterapkan ketika pandemi Covid-19. Sebagai solusinya, guru melaksanaksanakan pembelajaran secara khusus di sekolah bersama siswa yang terkendala dengan media pembelajaran berbasis TIK atau melakukan Home Visit secara berkala oleh wali kelas dari masing-masing siswa.

\section{DAFTAR PUSTAKA}

A. Sulaeman. (2019). Ict Dalam Pembelajaran Pendidikan Agama Islam. Https://Ump.Ac.Id/Hikmah-1418Ict.Dalam.Pembelajaran.Pendidikan.Agama.Islam.Html.

Asmuni. (2020). Problematika Pembelajaran Daring Di Masa Pandemi Covid-19 Dan Solusi Pemecahannya. Jurnal Paedagogy: Jurnal Penelitian Dan Pengembangan Pendidikan, 7(4), 281. Https://Doi.Org/10.33394/Jp.V7i4.2941

Cholis, A. N., Ningsih, M. L. W., \& Syifaussakinah, A. K. A. Z. (2020). Media Berbasis Powerpoint Untuk Pembelajaran Kosa Kata Bahasa Arab Bagi Pemula Dalam. Konferensi Nasional Bahasa Arab Vi, 12, 365-377.

Darimi, I. (2017). Teknologi Informasi Dan Komunikasi Sebagai Media Pembelajaran Pendidikan Agama Islam Efektif. Cyberspace: Jurnal Pendidikan Teknologi Informasi, 1(2), 117. Https://Doi.Org/10.1007/S11068-008-9037-4

Dewi, S. Z., \& Hilman, I. (2019). Penggunaan Tik Sebagai Sumber Dan Media Pembelajaran Inovatif Di Sekolah Dasar. Indonesian Journal Of Primary Education, 2(2), 48 Https://Doi.Org/10.17509/Ijpe.V2i2.15100

Dewi, W. A. F. (2020). Dampak Covid-19 Terhadap Implementasi Pembelajaran Daring Di Sekolah Dasar. Edukatif: Jurnal Ilmu Pendidikan, 2(1), 55-61. Https://Doi.Org/10.31004/Edukatif.V2i1.89

Handriyantini, E. (2020). Strategi Pembelajaran Daring Aktif, Kreatif Dan Menyenangkan. Bunga Rampai Rekonstruksi Pembelajaran Di Era New Normal (1 st Ed.). Seribu Bintang.

Hanifah Salsabila, U., Irna Sari, L., Haibati Lathif, K., Puji Lestari, A., \& Ayuning, A. (2020). Peran Teknologi Dalam Pembelajaran Di Masa Pandemi Covid-19. Al-Mutharahah: Jurnal Penelitian Dan Kajian Sosial Keagamaan, 17(2), 188-198. Https://Doi.Org/10.46781/Al-Mutharahah.V17i2.138

Muhson, A. (2010). Pengembangan Media Pembelajaran Berbasis Teknologi Informasi. Jurnal Pendidikan Akuntansi Indonesia, 8(2). Https://Doi.Org/10.21831/Jpai.V8i2.949

Nafrin, I. A., \& Hudaidah, H. (2021). Perkembangan Pendidikan Indonesia Di Masa Pandemi Covid-19. Edukatif: Jurnal Ilmu Pendidikan, 3(2), 456-462. Https://Doi.Org/10.31004/Edukatif.V3i2.324

Nugrahani, F. (2014). Metode Penelitian Kualitatif Dalam Penelitian Pendidikan Bahasa. In Cakrabooks (Cakra Book). Http://EJournal.Usd.Ac.Id/Index.Php/Llt\%0ahttp://Jurnal.Untan.Ac.Id/Index.Php/Jpdpb/Article/Viewfile/11345 /10753\%0ahttp://Dx.Doi.Org/10.1016/J.Sbspro.2015.04.758\%0awww.Iosrjournals.Org

Pramitha Putri, H. \& N. (2021). Edukatif: Jurnal Ilmu Pendidikan Pengaruh Media Pembelajaran Power Point Interaktif Terhadap Hasil Belajar Ips Siswa Sekolah Dasar. Edukatif: Jurnal Ilmu Pendidikan, 3(6), 3538-3543. Https://Doi.Org/10.31004/Edukatif.V3i6.986

Rahman, A. (2019). Pendidikan Islam Di Era Revolusi Industri 4.0 (Cetakan Pe). Komojoyo Press. Https://Doi.Org/10.31219/Osf.Io/4j6ur

Sadikin, A., \& Hamidah, A. (2020). Pembelajaran Daring Di Tengah Wabah Covid-19. Biodik: Jurnal Ilmiah 
1386 Media Pembelajaran Bahasa Arab Berbasis Teknologi Informasi Komunikasi pada Pembelajaran Daring di Sekolah Dasar - Almi Novita, Munawir

DOI: https://doi.org/10.31004/edukatif.v4i1.1947

Pendidikan Biologi, 6(2), 109-119. Https://Doi.Org/10.22437/Bio.V6i2.9759

Sugiyono. (2016). Metode Penelitian Kuantitatif, Kualitatif Dan R\&D. Pt. Alfabet.

Suriadi, H. J., Firman, F., \& Ahmad, R. (2021). Analisis Problema Pembelajaran Daring Terhadap Pendidikan Karakter Peserta Didik. Edukatif: Jurnal Ilmu Pendidikan, 3(1), 165-173. Https://Doi.Org/10.31004/Edukatif.V3i1.251

Suryani, N. (2015). Pengembangan Media Pembelajaran Berbasis It. Pengembangan Ict Dalam Pembelajaran, $1-14$.

Wahyuningtyas, R., \& Sulasmono, B. S. (2020). Pentingnya Media Dalam Pembelajaran Guna Meningkatkan Hasil Belajar Di Sekolah Dasar. Edukatif: Jurnal Ilmu Pendidikan, 2(4), 318-333.

Widianto, Edi., Dkk. (2021). Pemanfaatan Media Pembelajaran Berbasis Teknologi Informasi. Jete: Journal Of Education And Teaching, 2(2), 213-224.

Yazdi, M. (2012). E-Learning Sebagai Media Pembelajaran Interaktif Berbasis Teknologi Informasi. Jurnal Ilmiah Foristek, 2(1), 143-152. 